\title{
WOMAN-WARRIOR, WOMAN-MAN: RECOGNITION OF THE WORK AND ITS MEANINGS IN THE PERCEPTION OF FEMALE RECYCLING WORKERS
}

\author{
Alexa Pupiara Flores Coelhoํㅡ, Carmem Lúcia Colomé Beck², Marcelo Nunes da Silva Fernandes', Katiusci \\ Lehnhard Machado ${ }^{4}$, Silviamar Camponogara ${ }^{5}$
}

\footnotetext{
${ }^{1}$ Doctoral student, Programa de Pós-Graduação em Enfermagem, Universidade Federal de Santa Maria (UFSM). Santa Maria, Rio Grande do Sul, Brazil. Email: alexa.p.coelho@hotmail.com

2 Ph.D. in Philosophy of Nursing. Professor, Departamento de Enfermagem, Programa de Pós-Graduação em Enfermagem, UFSM. Santa Maria, Rio Grande do Sul, Brazil. Email: carmembeck@gmail.com

${ }^{3}$ M.Sc. in Nursing. Santa Maria, Rio Grande do Sul, Brazil. Email: marcelonsf@gmail.com

${ }^{4}$ M.Sc. in Psychology. Santa Maria, Rio Grande do Sul, Brazil. Email: klehnhard@yahoo.com.br

${ }_{5}^{5}$ Ph.D. in Nursing. Professor, Departamento de Enfermagem and of the Programa de Pós-Graduação em Enfermagem, of the UFSM. Santa Maria, Rio Grande do Sul, Brazil. Email: silviaufsm@yahoo.com.br
}

\begin{abstract}
The study aimed to reveal the recognition of the work and of its meanings in the perception of female recycling workers of a recycling cooperative. It is a qualitative, exploratory-descriptive study, undertaken with female recycling workers in a recycling cooperative in a municipality of the central region of the State of Rio Grande do Sul, Brazil. The data were produced through participant observation, semistructured interviews (held with seven women) and focus groups (with six women), between July and August 2013; the data were analyzed using content analysis. The results show that the dynamic of the recognition is complex and involves situations of valorization and of prejudice. The female workers elaborate individual and collective meanings for the work which they undertake, represented, principally, by the self image of "Woman-warrior" and "Woman-man". It is concluded that recognition and meanings of the work correlate with how the female recycling workers experience and understand their work.
\end{abstract}

DESCRIPTORS: Occupational health. Women, working. Solid waste segregators. Qualitative research. Nursing.

\section{MULHER-GUERREIRA, MULHER-HOMEM: RECONHECIMENTO DO TRABALHO E SEUS SENTIDOS NA PERCEPÇÃO DE MULHERES RECICLADORAS}

\begin{abstract}
RESUMO: O objetivo do estudo foi revelar o reconhecimento do trabalho e seus sentidos na percepção de mulheres recicladoras de uma cooperativa de reciclagem. Estudo qualitativo, exploratório-descritivo, realizado com recicladoras em uma cooperativa de reciclagem de município da região central do Rio Grande do Sul, Brasil. Os dados foram produzidos por meio da observação participante, entrevista semiestruturada (realizada com sete mulheres) e grupos focais (com seis mulheres), entre julho e agosto de 2013, e analisados por meio da análise de conteúdo. Os resultados mostram que a dinâmica do reconhecimento é complexa e envolve situações de valorização e de preconceito. As trabalhadoras elaboram sentidos individuais e coletivos para o trabalho que desempenham, representados, principalmente, pela autoimagem da "mulher-guerreira" e "mulher-homem". Concluiu-se que reconhecimento e sentidos do trabalho se correlacionam no modo como as recicladoras vivenciam e compreendem seu trabalho.
\end{abstract}

DESCRITORES: Saúde do trabalhador. Trabalho feminino. Catadores. Pesquisa qualitativa. Enfermagem.

\section{MUJER-GUERRERA, MUJER-HOMBRE: RECONOCIMIENTO DEL TRABAJO Y SUS SENTIDOS EN LA PERCEPCIÓN DE MUJERES RECICLADORAS}

RESUMEN: El objetivo del estudio fue revelar el reconocimiento del trabajo y sus sentidos en la percepción de mujeres recicladoras de una cooperativa de reciclaje. Estudio cualitativo, exploratorio, descriptivo, realizado con recicladoras de una cooperativa de una ciudad de la región central del Rio Grande do Sul, Brasil. Los datos fueron recolectados por medio de observación participante, entrevista semiestructurada (realizada con siete mujeres) y grupos focales (con seis mujeres), entre julio y agosto de 2013, y analizados por medio de análisis de contenido. Los resultados muestran que la dinámica del reconocimiento es complexa y envuelve situaciones de valorización y de preconcepto. Las trabajadoras elaboran sentidos individuales y colectivos para el trabajo que desempeñan, representado, principalmente, por la auto-imagen de "mujer-guerrera" y "mujer-hombre". Se concluye que reconocimiento y sentidos del trabajo se correlacionan en el modo como las recicladoras vivencian y comprenden su trabajo.

DESCRIPTORES: Salud laboral. Trabajo de mujeres. Segregadores de residuos sólidos. Investigación cualitativa. Enfermería. 


\section{INTRODUCTION}

With the advent of modern urban society and of the industry of production and consumption, with the development of technological and economic progress, one phenomenon experienced by the major cities is the increase in the production and discarding of solid waste. This new context has made it possible to have discussions about the role of the recycler, a worker who is surrounded by stigmatized social imaginaries, and, due to being involved with products discarded by society, has his or her image associated with the act of discarding itself. ${ }^{1}$

The problem referent to the role of recycler takes into account his or her social place, as a worker in the productive chain. In this aspect, discussion is necessary regarding this subject's health and wellbeing, in particular, of the recognition of his or her work and the feelings attributed by these subjects. The recognition and the meanings of the work are concepts arising from the psychodynamic of work, a scientific approach developed in France by Christophe Dejours, a psychiatrist and psychoanalyst. Its conceptual bases are grounded in epistemological roots of the hermeneutic, and originate from the dialogue between psychoanalyst, philosophy, sociology and ergonomics. ${ }^{2}$

It is underlined that the psychodynamic of work proposes thinking about the articulation of the work and the psychic balance of the workers, which is fundamental if these are to be able to keep themselves healthy in their work environment. Therefore, the psychodynamic makes it possible to construct and reconstruct the relationships between the worker and the solid reality with the work. ${ }^{3}$

The recognition of the work can be defined as the articulation between visibility, appreciation and judgment of usefulness on the worker and the product of her activities, based on which she herself feels recognized by her colleagues and by society. ${ }^{4}$ This recognition occurs in relation to the work in itself, not regarding the subject, which makes the activity into a means for the recognition of the worker. ${ }^{5}$ Furthermore, it is possible to obtain this through the mediation of the view of the others in the set of the work relationships.

On the other hand, the meanings of the work allow the subject to construct her personal and professional identity, being able, therefore, to identify with the task undertaken. These are peculiar to each worker, as they are created based on unique experiences. In order to maintain their health, the work needs to make sense to them, to their group of colleagues, and to the society in which they are integrated. ${ }^{6}$ Therefore, as with the recognition, the meaning of the work is central in relation to the health and well-being of the recycling worker.

The issue of the health of the recycler in the perspective of the psychodynamic of work has been explored little in nursing research. One narrative review undertaken in 2013, in the Latin American and Caribbean Health Sciences Literature (LILACS) and Medical Literature Analysis and Retrieval System Online (MEDLINE) databases, based on the research question "What has been produced regarding the health of recycling workers?" evidenced the shortage of research addressing subjective aspects of the work for these subjects, such as pleasure, suffering, invisibility, meanings of the work, perceptions and feelings.

Furthermore, it was observed that there are few studies directed towards female work in recycling, a fact which does not converge with evidence of the striking presence of women in this scenario..$^{7-8}$ Finally, emphasis is placed on the incipient presence of nursing in the production of knowledge regarding recycling workers' health, a presence which is necessary, bearing in mind that nursing has an ethical commitment to the health and quality of life of the community, having as a principle the promotion of the human being as a whole, meeting the precepts of ethics and of bioethics. ${ }^{9}$

Within this perspective, this study's objective was to reveal the recognition of the work and its meanings and the perception of female recycling workers of a recycling cooperative.

\section{METHOD}

The present study was comprised of a qualitative investigation, of the exploratory descriptive type, undertaken in a cooperative for selecting recyclable materials located in a municipality in the central region of the Brazilian state of Rio Grande do Sul. This cooperative is responsible for selective collection in the municipality, and undertakes the gathering, separation and sale of recyclable materials, or their distribution to smaller cooperatives. It is located on the urban perimeter of the above-mentioned municipality. At the time of data production, the cooperative was staffed by six men and nine women in the recycling activity, who made up the study participants.

The selection of the female workers for the study took place through the following inclusion criteria: to be a woman who worked in activities of selecting recyclable materials, linked to the co- 
operative; to have worked for at least six months in the activity in question, due to the need to avoid female workers who had had little contact time with the work. For exclusion criteria, the following was established: female workers who were off work in the data collection period for any reason.

Three techniques were used for producing the data: participant observation; semistructured interviews; and the focus group (FG) technique.

Participant observation includes direct contact between the researcher and the subjects in the cultural context, allowing the understanding of the facts and of the interaction between the subjects within their context. ${ }^{10}$ In this phase, after the acceptance of the cooperative, over a period of five days (totaling a mean of 25 hours of observation) the work routine was observed in the recycling warehouse and interaction and dialogue were sought with the female workers. An observation script and a field diary were used. For the semistructured interview, on the other hand, seven female workers met the inclusion criteria and were, therefore, included in this stage. The interviews took place in July 2013, in the cooperative's headquarters. The women were identified by the letter W, for "worker", followed by a number corresponding to the order of the interviews (W1, W2, W3... W7).

Regarding the FG, this aims to obtain qualitative data through a group interaction between the subjects, mediated by a moderator, in which the focus is an issue common to all. ${ }^{11}$ Three FG sessions were held, in the first two of which five women participated, and in the third, six. All the women who participated in the FGs had previously participated in the interviews. In each session, guiding questions were proposed, which led the debate. This role was performed by the moderator, who was responsible for fostering the dialogue and leading it to the focus of the study. In addition to this, three research assistants participated, who were responsible for making notes identifying the workers' accounts by their names, who noted nonverbal communication and who summarized the content of the debates. This summary was read at the end of the sessions, with the workers being able to corroborate or change it.

The identification of the female workers in the records of the FGs was undertaken through the use of pseudonyms which were chosen by each woman and which were written on ID badges in colored pen. This stage occurred in August 2013 in the cooperative's headquarters.

The semistructured interviews and FGs were recorded using mp3 digital recording devices, with the consent of all the women. They were later transcribed in full, using the Microsoft Word Starter $2010^{\circledR}$, with a view to greater reliability in the analysis of the data.

For analysis of the material, the technique of thematic content analysis was used, undertaken in three stages: pre-analysis; exploration of the material; and analysis of the data and interpretation. ${ }^{12}$ In the pre-analysis, the transcribed material was organized in the light of the objectives and read exhaustively. Later, groupings were made through two techniques: the synoptic framework, which related each account to its extract, to the impressions of the researcher and to the objective to which they were related. The second technique, cutting out by colors, consisted of attributing keywords to the accounts, to each of which a color was attributed. The extracts of the accounts were colored according to the keywords, were cut out, and later grouped by color. The groups of accounts were glued in a notebook in larger groups, each one representing one of the study objectives. Both techniques aimed to validate themselves, and the groupings obtained in both converged.

In the second phase, exploration of the material, the data are taken apart and coded in record units (RUs) - a word, or set of words, summarizing the idea of an account - and, in this way, a view is obtained of the characteristics of the results. ${ }^{12}$ Thus, in each extract of the account, its RU was highlighted. Afterwards, the RUs were grouped by their semantic affinity. The process was undertaken doubly, that is, in the synoptic framework and in the notebook of colors, and both processes culminated in the same groupings, thus being validated.

Finally, in the treatment of the data and interpretation, the researcher, in possession of substantial results, makes her inferences and interpretations. ${ }^{12}$ At this point, the field diary of the participant observation was re-read in depth. Excerpts were removed from the field diary and annexed, in note format, throughout the notebook containing the colored items, in accordance with the complementarity of the information in the notes of the diary with the excerpts of the notebook containing the colored items. As a result, the information from the field diary was incorporated into the notebook, in such a way that the data were summarized and compared in this third phase of the analysis.

Through this, it was possible to organize the groupings into thematic categories and subcategories. In this article, two categories of the set of the results obtained will be presented: From prejudice to 
recognition of the work: the search for respect; and The "woman-warrior, woman-man": construction of the meanings of the work.

This study was in conformity with Resolution 466/12 of the Brazilian National Health Council. ${ }^{13}$ All the participants signed the Terms of Free and Informed Consent. The study was approved by the Research Ethics Committee of the Universidade Federal de Santa Maria, the number of the Certificate of Presentation for Ethical Consideration, being 16195113.9.0000.5346.

\section{RESULTS AND DISCUSSION}

In relation to the sociodemographic and occupational characteristics, the mean age mentioned by the women was 42 years old. The minimum age mentioned was 30 years old, and the maximum, 53. All the women were literate. Of the seven women, five were married or had a partner, and six mentioned having children, with a mean of three children each. The women's mean time of work in the recycling center was 8.8 years, it being the case that the woman who had been in the profession longest had 19 years of experience, and the most recent, 3.5 years of experience. When questioned regarding the reasons for entering recycling work, the predominant reports were, respectively: unemployment and difficulty in entering the formal work market; cooperative work as a possibility for improving income; curiosity and identification with the tasks; and the influence of family members who already undertook the activity.

\section{From prejudice to the recognition of the work: the search for respect}

The female workers mentioned issues related to how they were seen by society, by their family, and by the people with whom they coexist in their day-to-day. In these reports, elements were present related as much to the prejudice regarding their work as to the valorization and struggle for social prestige.

The female workers' reports referent to the prejudice experienced in some situations were striking. The pejorative use of the word "trashman" and the association of the image of the recycler with the figure of an alcoholic and untrustworthy man were emphasized by the female recycling workers.

People don't have respect for us. They call us trashmen. We disgust them. [...] They say things about us, and disrespect our work (Patrícia).
[...] The people are prejudiced against us, the people from our neighborhood, our neighbors (W5).

People see the recyclers on the street, and because some are drunk, some are dirty, just some, not all are! They think that we are like that. And that is not how it is! (Manoela).

And they think sometimes that you are a thief, just because you're working [in recycling], they think 'Ah, that guy over there steals', you know? People think that about us (Patrícia).

During the participant observation, situations of discrimination were not witnessed. However, the female recycling staff often mentioned the need to leave the front of the cooperative "clean of waste", as - according to them - the neighborhood was not comfortable with the presence of the recyclable material. Research has evidenced that recycling professionals feel the prejudice in the way that others look at them, and suffer comparisons with the pejorative elements "garbageman, beggar, vulture, thief". ${ }^{14}$ This data supports the results found and suggests that the situations of nonrecognition of their work are recurrent among these workers.

The understanding that there is criticism originating from society is constructed by the recycler based on the association of this with the figure of the thief, of the beggar, and of the scoundrel, and these stereotypes mark the worker's relationship with other members of society. ${ }^{15}$ Therefore, the disqualification and the association of their tasks with pejorative elements may lead to feelings of suffering or even psychic illness.

It is emphasized that this has a fundamental role in the constituting of the worker's identity, being a link between the subject and the reality. ${ }^{5}$ The identity is a subjective experience, supported in the reality and in the recognition of others, in order to give meaning to the work. Furthermore, for the worker to remain healthy in the dynamic of pleasure and suffering in the work, it is important that he feels that his contribution is valued. ${ }^{16}$

Evidence was found, at other points, for opposite situations, of recognition and respect. The female recyclers mentioned that, although episodes of lack of recognition were recurrent, some segments of society, and their families, value and respect their work, as the following reports evidence:

Even my sister-in-law, who is 11 years old. The other day my mother-in-law said '[the girl's name] said that she wants to work with you, because when she went there, she liked what you were doing' (Julinha). 
[...] Because if we are entering people's houses, if we are welcome, it's because they see us differently. There are people who respect us (Mônica).

The dynamic of the recognition reflects the importance of the other, and of the work collectives, in relation to the judgment regarding who the subject is and the value of what he does. ${ }^{16}$ Therefore, constructing oneself as a worker involves, before anything, reuniting and incorporating the pre-existing constructions around oneself and one's tasks, confronting negative and positive stereotypes which permeate and influence one's being in the world.

Furthermore, the female workers emphasized the struggle to construct their image and the mobilization against prejudice, as shown below: [...] Although we deal with material which they call garbage, let them not call us garbagemen. That denigrates us. Recycler! That is so beautiful, so charming, we grow in this, our self-esteem (Manuela).

[...] Just because I work in the material, amidst garbage, as they say, does not mean that I have to live like garbage, not at all! (W6).

[...] I will never let anybody call me a trashman, never! Because that is not what I am, I have respect for my work (Mônica).

The female recycling workers' reports reveal a subjective and collective mobilization regarding questioning prejudice, the nonrecognition and the stereotypes constructed around them. This data points to a collective construction among the participants in this study in the sense of self-valorizing the work undertaken, which differs from results found in a study which evidenced, among the recyclers studied, feelings of shame and discouragement resulting from the nonrecognition of their work. ${ }^{14}$

The self-valorization of the work was underlined by the female workers at many points. The women show the importance of the worker being proud of being a recycler, and visualize this same pride in their family. As a result, the recognition of the work is re-vindicated, although the female recyclers stress the relevance of the subject herself recognizing herself and being proud of her profession, as well as the family members who benefit from the gains from the work in recycling.

[...] If you have the support of your family, if they are proud of what you do, you walk with your head up, you do not need to be ashamed. [...] We pay our bills, we keep our children in school, walk in the street like any other person, like any normal worker. What we are doing here is our job. [...] There is nothing for us to be ashamed of, because we support them from here, and how are you going to be ashamed of where you earn your bread? You have to be proud. [...] And here we are, proud, doing our job (Mônica).

In the absence of the recognition of the work, the worker's tendency is to demoralize and, in these cases, severe consequences can be triggered for their psychic health. ${ }^{4}$ In addition to this, the recognition is articulated with the feelings of suffering, that is, from the moment that the worker feels herself to be recognized, her frustrations and distress come to be re-signified and the suffering, to be faced by the subject in a new perspective. ${ }^{17-18}$ Therefore, from the moment in which the female recyclers emphasize the importance of pride in their work for the construction of the recognition, they are working towards re-signifying the daily suffering and constructing a healthy relationship with their work.

The results bring evidence that the dynamic of the recognition of the female recyclers' work is complex, to the extent that it involves opposing situations of disfavor/prejudice and valorization/ recognition. Furthermore, they evidence that the female workers seek, through the meanings attributed particularly by family members, to strengthen the social construction of their work. It is considered that this data is interlinked with the construction of the identity made clear in the subcategory below.

\section{The "woman-warrior,woman-man": the construction of the meanings of the work}

The women recognize the value of their work and the central role that this performs in their family's financial independence and sustentation. The value of the work is recognized to the extent that they perceive that having one's own income and being able to promote well-being for the family is a source of pride and satisfaction.

[...] Our family depends on our work, at home, there is somebody waiting. Our bills, the food, the day-to-day, like it or not we earn our bread here. And if we are struggling for it, we want the best (Manoela).

[...] You were dependent for everything! There's nothing worse than having to ask your husband, because you haven't got pads, is there anything worse than you telling him that you need your medication? There isn't. This here gives us our freedom (Mônica).

I depended a lot on my parents. And it is difficult, but once I started working and having my own things, I no longer depended on a man, on any husband (Patrícia).

The importance of the role that the work performs in the life of Man is related to the possibility of guaranteeing suvival. ${ }^{19}$ One can perceive that the 
women who select the materials value the financial return given by the work and attribute to this their female independence and the maintenance of the supporting of their families. However, one can observe that the value attributed to the work goes beyond the limits of the earnings, being also related to the subjective gains, which, for them, permeate the recycling.

We find a lot of perfumes, a lot of jewels, a lot of things which make us beautiful, how we like that! It's not because we work in the middle of the... as they say, 'of the garbage', it is not garbage, it is recyclable material... but we like to feel good, put on a good perfume, when we find it, we put it on... Even if it is very strong, we like it. We find good clothes, which we share out (Manoela).

The female recyclers' work meets a broad set of needs, not only financial, also bringing daily pleasures and satisfactions. The value of the work, for the women, is related to the meanings that the same has for each worker, meanings that are constructed individually and collectively.

This data was also identified during the participant observation. When the material from the selective collection arrived, many objects perfectly good to use were separated from the rest and distributed among the female recyclers, such as clothes, domestic utensils and even functioning electronic devices. Some female recyclers commented that, over the years spent working in the cooperative, they had improved the comfort in their home through acquiring objects deriving from the selective collection.

Work is considered the means through which people transform their environment and themselves, representing an instrument of the worker's social and individual construction. ${ }^{20}$ In order for a person to be able to construct themselves socially and subjectively as a worker, she elaborates meanings for the work which she performs, which represent mechanisms of professional realization and neutralization of the suffering. ${ }^{21}$

The meaning of the work is understood as the articulation of two components: the significant content in relation to the subject and the significant content in relation to the object. The first relates to the symbolic content and to the signification related to a specified profession and to the implicit social position linked to the same, while the second relates to the symbolic and material content constructed around the object of work, ${ }^{6}$ in the case of this study, recycling. It is emphasized that the meanings constructed by the female recyclers regarding themselves, working subjects, are evidenced in the account: I'm talking about us being super women... The work which we do, which is difficult, makes us worth ten men [...] (Nina).

The content of the account shows that the women built a symbology for themselves as female workers: that of Superwoman. This symbology is related to the physical effort and to the daily incidences of overcoming in manual work, which causes them to feel that they "are worth ten men". This conception is part of the construction of the meaning of the work. In relation to the meanings in relation to the object, corresponding to the symbolic content, these are evidenced in the following report:

I used to think that this was garbage. Now I have learned that it is not garbage. Imagine where all of this used to go. I wasn't bothered about this, but after I entered this area, after I saw, it began to bother me a lot, even throwing paper on the ground (Patrícia).

[...] No matter how much they say it is garbage, it is not garbage! It is material which has been discarded. It is a wrapper, and it will be used again. You will use it again (Manoela).

The recycling has, for the women, the meaning of preserving nature, of sustainability. They understand that the object of their work represents a material which, thanks to their actions and their work, will continue its cycle and return to be consumed by society.

The meaning of the work relates to its underlying value and to the coherence which the same has for the worker. ${ }^{22}$ Therefore, through the construction of symbols which represent the value and the coherence of the role that they perform, the female recyclers construct the meanings of their work in the cooperative and, through this, signify it and transform it into an element of pleasure and of health.

The work represents a source of pleasure and actualization, to the extent that it expresses the most human of what exists in man: the capacity to imprint and manifest his subjectivity, a crucial element for human balance and development. ${ }^{23}$ In this regard, the female recyclers have in their work an element of pleasure and of health, as, through imprinting their subjectivity on the tasks and constructing meanings for them, they transform them into instruments of actualization.

I like what I do. [...] I consider myself to be very important for nature, for the life of my children, and for my grandchildren (W5).

[...] You have professional growth, you have personal growth, you can grow as a person. You can pass 
on to other people the importance of what you are doing, which I think is a big thing (Mônica).

I feel fulfilled because of being able to do what I do. What I do here is service to humanity. Because of this, I feel fulfilled, because of being able to do this (Julinha).

Fulfilled. Because we try to do as much as possible. You feel fulfilled because you go the extra mile. You get to the point that your arms are aching and you are still going. It's like the day of an examination coming, and you getting full marks (Nina).

The search for pleasure passes along the route of re-signification of the suffering, to the extent that the individual seeks means of obtaining the stability of the psychic apparatus and the conciliation with her subjectivity. ${ }^{25}$ The accounts show that the female recyclers use the agents of suffering themselves - the physical strain, the exhaustion of the body - and transform them into elements of pride and satisfaction. This exemplifies the re-signification of the suffering. It also shows how they managed to cope with the adversities of their work and construct, individually and collectively, meanings for the tasks that they perform, and a self image as workers.

Regarding the construction of the self-image, it is understood that this is a collective movement, in which the female recyclers formulated, together, a symbol regarding themselves involving the female, strength, and empowerment. This symbol was expressed mainly through the ideas of "womanwarrior" and "woman-man". Some excerpts illustrate the use of this image by the women:

It is that the woman becomes a little bit male [...], the warrior woman, she who works, because she has a house to support, she has children, generally they are separating, and it is generally the second, the third, the fourth, the fifth marriage... But the woman knows that the responsibility is not shared with the husband (Manuela).

[...] Just us, real female warriors, to embrace this. This is what I say to the girls. [...] And we are indeed warriors! (Nina).

The "woman-warrior", for the female workers, represents the woman who works and who is responsible for commanding and supporting her family. She faces all the difficulties but does not perish through the inflexibility and demands of the work, neither through the tasks existing in the home. The "woman-man", on the other hand, brings the male closer to the female. The male represents strength, command, resistance; the women appropriate the social representation of the male in order to symbolize the set of their qualities which they consider close to virility.
There exists, in the universe of work, a set of characteristics attributed to virility. Generally, these characteristics are related to strength, authority, commanding and to power. Virility is a symbol upon which is founded the understanding that each sex fits into a predefined social place. ${ }^{17}$ However, one can perceive that the female recyclers have elaborated another collective meaning for this representation. Instead of understanding virility in the other, in the man, they have appropriated this symbol and its qualities, constructing the self image of a strong and resistant woman.

One can think, therefore, that the construction of the representation of the "woman-warrior" and of the "woman-man" meets the role of creating the female workers' defense against suffering. Understanding themselves as strong, solid, virile and resistant women helps the selecters to face the challenges, the difficulties, the exhaustion, the pain, the suffering and the illness which affect them daily. Therefore, more than just constituting a defensive strategy in the work, the representation of "woman-warrior" and of "woman-man" is an instrument of health, as the same construct, based on this, the significant content in relation to themselves as one of the elements of the construction of the meaning of the work. ${ }^{6}$

It is understood, therefore, that the way that the female recyclers experience their tasks is influenced by the value and meanings which the same attribute to the work performed. The meanings of the work act as neutralizers of the suffering, to which are opposed strategies which stop the work from being arduous to the point of it no longer being possible to manage the daily routine.

Besides this task of neutralizing the suffering, the meanings of the work are able to transform the work activities into vehicles of pleasure, satisfaction and health. Thanks to this articulated process of signification of the activities and of the construction of an image as a worker, the women find coherence and importance in the tasks which they perform, and are therefore capable of transforming the suffering into pleasure.

\section{FINAL CONSIDERATIONS}

The woman who works in recycling, in exercising her work, faces situations of prejudice and devalorization, which result in the nonrecognition of her social role. On the other hand, she recognizes that there are times in which there is return from her family and from society, which allow experiences of pleasure and actualization. 
The suffering arising from the difficulties met on a daily basis by the female recycler is faced through the meanings which she constructs, individually and collectively, around the work which she undertakes. In the light of the results obtained in this study, it was evidenced that the women encourage themselves and construct meanings for the work which go beyond the superficiality of material gains, such that the activity of recycling gains another connotation, subjective and singular, of independence, overcoming, resistance and the possibility of improvement in quality of life.

In relation to this study's limitations, it is considered that the fact of giving a voice to the female recycling staff in a cooperative excludes, in a certain way, a wide set of recyclers who exercise their activities on the public highways and in the landfill sites. It is necessary that research regarding the experiences of pleasure, suffering, recognition and meanings of the work for the recyclers should reach these professionals in the different situations of life and work, in the various scenarios of work, so as to indicate similarities, differences, and possibilities for intervention.

This study sought to articulate the knowledge of the field of nursing with the health of the woman who works in recycling, so as to offer support for the work of the professional nurse, particularly taking into account the importance of advancing toward care which goes beyond the mere undertaking of actions focused on resolving acute health issues. It is considered that the nursing care for the health of workers (and among these, the recycler) must take into account their subjectivity, their way of relating to the work and to society, their experiences of life and their unique experiences, articulating actions of education, health promotion, research and extension, with the aim of giving them a voice, visibility, and promoting health and pleasure in the exercising of their work.

Emphasis is placed on the role of the nurse in the construction of the knowledge in occupational health and, in particular, of workers who are remembered little in the scientific field, such as recyclers. Nursing's movement in the direction of these subjects is fundamental for the consolidation of the integrity and the universality of the care.

\section{REFERENCES}

1. Pereira JCS, Godoi CK, Coelho ALAL. Qualidade de vida dos catadores de materiais recicláveis: um estudo etnográfico. Gestão Sociedade. 2012; 6(14):159-77.
2. Merlo ARC, Mendes AMB. Perspectivas do uso da psicodinâmica do trabalho no Brasil: teoria, pesquisa e ação. Cad Psicol Soc Trab. 2009; 12(2):141-56.

3. Santos Júnior AV, Lima VS, Facas EP, Mendes AMB. Trabalho prescrito, real e estratégias de mediação do sofrimento de jornalistas de um órgão público. Sistemas \& Gestão. 2012; 6: 562-82.

4. Dejours C. Psicodinâmica do trabalho: contribuições da Escola Dejouria na análise da relação prazer, sofrimento e trabalho. São Paulo (SP): Editora Atlas; 1994.

5. Athayde V, Hennington EA. A saúde mental dos profissionais de um Centro de atenção Psicossocial. Physis (Rio J.). 2012; 22(3):983-1001.

6. Dejours C. A loucura do trabalho: estudo de psicopatologia do trabalho. $5^{\text {a }}$ ed. São Paulo (SP): Cortez - Oboré; 1992.

7. Sander FP, Silva DAK, Baldin, N. A valorização do ser humano e de sua criatividade mediante atividade artesanal com embalagens plásticas: o caso das catadoras de União Vitória/PR. G\&DR. 2011 Set-Dez; 7(3):134-57.

8. Riqueti CE, Couto GA. Hábitos de consumo entre catadores de materiais recicláveis: uma abordagem metodológica. Olhar de Professor. 2010; 13 (2):267-77.

9. Conselho Federal de Enfermagem. Resolução n. 311/2007. Aprova a Reformulação do Código de Ética dos Profissionais de Enfermagem- CEPE. Conselho Federal de Enfermagem, 08 Fev 2007.

10. Correia MCB. A observação participante enquanto técnica de investigação. Pensar Enferm. 2009; 13(2):30-6.

11. Ressel LB, Beck CLC, Gualda DMR, Hoffmann IC, Silva RM, Sehnem GD. O uso do grupo focal em pesquisa qualitativa. Texto Contexto Enferm. 2008; 17(4):779-86.

12. Bardin, L. Análise de conteúdo. $8^{\mathrm{a}}$ ed. Portugal (PT): Geográfica Editora; 2011.

13. Ministério da Saúde (BR), Conselho Nacional de Saúde, Comissão Nacional de Ética em Pesquisa. Resolução n 466 de 12 de dezembro de 2012: diretrizes e normas regulamentadoras de pesquisa envolvendo seres humanos. Brasília (DF): MS; 2012.

14. Maciel RH, Matos TGR, Borsoi ICF, Mendes ABC, Siebra PT, Mota CA. Precariedade do trabalho e da vida de catadores de recicláveis em Fortaleza, CE. Arq Bras Psicol. 2011; 63 (Esp):71-82.

15. Miura PO, Sawaia BB. Tornar-se catador: sofrimento ético-político e potência de ação. Psicol Soc. 2013; 25 (2):331-41.

16. Bendassolli PF. Reconhecimento no trabalho: perspectivas e questões contemporâneas. Psicol Etud. 2012; 17(1):37-46.

17. Dejours C. A banalização da injustiça social. $7^{a}$ ed. Rio de Janeiro (RJ): Editora FGV; 2006.

18. Traesel ES, Merlo ARC. A psicodinâmica do reconhecimento no trabalho de enfermagem. Psico. 2009; 40(1):102-9. 
19. Oliveira AS. Sobre o sentido do trabalho: entre Frankl e Dejours. [trabalho de conclusão de curso]. Campina Grande (PB): Universidade Estadual da Paraíba; 2013.

20. Beck CLC, Prestes FC, Tavares JP, Silva RM, Prochonow AG, Nonnemacher CQ. Identidade profissional de enfermeiros de serviços de saúde municipal. Cogitare Enferm. 2009 Mar-Mai; 14(1):114-9.

21. Dejours C. A avaliação do trabalho submetida à prova do real. São Paulo (SP): Blucher; 2008.
22. Morin EM, Aubé C. Psicologia e Gestão. São Paulo (SP): Atlas; 2009.

23. Dejours C. Uma nova visão do sofrimento humano nas organizações. In: Torres OLS, organizador. O indivíduo na organização: dimensões esquecidas. $3^{\text {a }}$ ed. São Paulo (SP): Atlas; 1996.

24. Mendes, AMB. Psicodinâmica do trabalho: teoria, método e pesquisas. São Paulo (SP): Casa do Psicólogo; 2007. 